\title{
Retraction Note to: TREM-1 associated macrophage polarization plays a significant role in inducing insulin resistance in obese population
}

\author{
Saravanan Subramanian ${ }^{1}$, Pradeep K. Pallati ${ }^{2}$, Poonam Sharma ${ }^{3}$, Devendra K. Agrawal ${ }^{1}$ \\ and Kalyana C. Nandipati ${ }^{1,2^{*}}$
}

\section{Retraction Note to: J Transl Med (2017) 15:85 \\ https://doi.org/10.1186/s12967-017-1187-7}

This article [1] has been retracted at the request of the authors. Upon re-review of the data, we realized certain patients did not meet inclusion criteria. Per IRB guidelines, after removing three subjects who either had $\mathrm{BMI}>65$ or $\mathrm{BMI}<40$ (even though they had undergone bariatric surgery) and one control subject from the study, we re-analyzed the data set. The removal of these subjects from the analysis had no effect on our findings or conclusions. The journal's Editor-in-Chief has invited the authors to re-publish their study with updated results.

All authors agree to this retraction.

\section{Author details}

${ }^{1}$ Department of Clinical and Translational Science, Creighton University School of Medicine, Omaha, NE, USA. ${ }^{2}$ Department of Surgery, Creighton University School of Medicine, 601 N. 30th Street, Suite \# 3700, Omaha, NE 68131, USA. ${ }^{3}$ Department of Pathology, Creighton University School of Medicine, Omaha, NE, USA.

Published online: 13 May 2020
Reference

1. Subramanian S, Pallati PK, Sharma P, Agrawal DK, Nandipati KC. TREM-1 associated macrophage polarization plays a significant role in inducing insulin resistance in obese population. J Transl Med. 2017;15:85. https:// doi.org/10.1186/s12967-017-1187-7.

\section{Publisher's Note}

Springer Nature remains neutral with regard to jurisdictional claims in published maps and institutional affiliations.

(c) The Author(s) 2020. This article is licensed under a Creative Commons Attribution 4.0 International License, which permits use, sharing, adaptation, distribution and reproduction in any medium or format, as long as you give appropriate credit to the original author(s) and the source, provide a link to the Creative Commons licence, and indicate if changes were made. The images or other third party material in this article are included in the article's Creative Commons licence, unless indicated otherwise in a credit line to the material. If material is not included in the article's Creative Commons licence and your intended use is not permitted by statutory regulation or exceeds the permitted use, you will need to obtain permission directly from the copyright holder. To view a copy of this licence, visit http://creativeco mmons.org/licenses/by/4.0/. The Creative Commons Public Domain Dedication waiver (http://creativecommons.org/publicdomain/ zero/1.0/) applies to the data made available in this article, unless otherwise stated in a credit line to the data. 